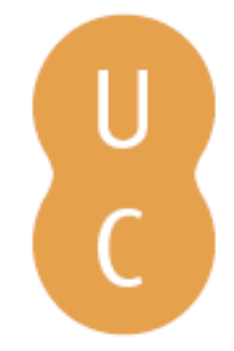

\title{
nommalina
}

\section{Defining and mapping the wildland-urban interface in Portugal}
Autor(es):
Pereira, José M. C.; Alexandre, Patrícia M.; Campagnolo, Manuel L.; Bar-Massada, Avi; Radeloff, Volker C.; Silva, Pedro C.

Publicado por: Imprensa da Universidade de Coimbra

URL persistente:

URI:http://hdl.handle.net/10316.2/44598

DOI:

DOI:https://doi.org/10.14195/978-989-26-16-506_81

Accessed : $\quad$ 26-Apr-2023 12:38:06

A navegação consulta e descarregamento dos títulos inseridos nas Bibliotecas Digitais UC Digitalis, UC Pombalina e UC Impactum, pressupõem a aceitação plena e sem reservas dos Termos e Condições de Uso destas Bibliotecas Digitais, disponíveis em https://digitalis.uc.pt/pt-pt/termos.

Conforme exposto nos referidos Termos e Condições de Uso, o descarregamento de títulos de acesso restrito requer uma licença válida de autorização devendo o utilizador aceder ao(s) documento(s) a partir de um endereço de IP da instituição detentora da supramencionada licença.

Ao utilizador é apenas permitido o descarregamento para uso pessoal, pelo que o emprego do(s) título(s) descarregado(s) para outro fim, designadamente comercial, carece de autorização do respetivo autor ou editor da obra.

Na medida em que todas as obras da UC Digitalis se encontram protegidas pelo Código do Direito de Autor e Direitos Conexos e demais legislação aplicável, toda a cópia, parcial ou total, deste documento, nos casos em que é legalmente admitida, deverá conter ou fazer-se acompanhar por este aviso. 


\section{ADVANCES IN}

\section{FOREST FIRE RESEARCH}

\section{8}

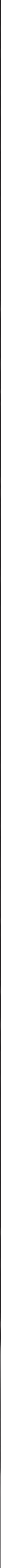




\title{
Defining and Mapping the Wildland-Urban Interface in Portugal
}

\author{
José M.C. Pereira*1; Patrícia M. Alexandre" ${ }^{1}$; Manuel L. Campagnolo; Avi Bar-Massada ${ }^{2}$; Volker \\ C. Radeloff ${ }^{3}$; Pedro C. Silva ${ }^{1}$ \\ ${ }^{1}$ Centro de Estudos Florestais, Instituto Superior de Agronomia, Universidade de Lisboa. Tapada \\ da Ajuda, 1049,Lisboa, \{jmcpereira@isa.ulisboa.pt*, palexandre@isa.ulisboa.pt, \\ mlc@isa.ulisboa.pt,pcsilva@isa.ulisboa.pt\} \\ ${ }^{2}$ Department of Biology and Environment, University of Haifa. Oranim, Kiryat Tivon 36006, \\ Israel, \{barmassada@gmail.com\} \\ ${ }^{3}$ SILVIS Lab, Dep. Of Forest and Wildlife Ecology, University of Wisconsin-Madison, USA. \\ Linden Drive, \{radeloff@wis.edu\}
}

\begin{abstract}
Wildfires in Portugal often threaten urban areas, from small rural villages to the edges of large cities. Regional variations in land use and human settlement patterns originate diverse types of wildland-urban interface (WUI), which need to be mapped to aid decisions concerning landscape-scale fire prevention and suppression. We propose a novel definition of the WUI as the set of line segments where urban areas are in immediate physical contact with flammable vegetation (direct interface), or are less than a pre-specified distance away from flammable vegetation (indirect interface). We also develop a methodology to map it in detail over large areas, based on spatial analysis of the vertices of urban and wildland polygons derived from reclassifying a land cover map. Our approach to WUI delineation mapped $29977 \mathrm{~km}$ of direct WUI and 11192 $\mathrm{km}$ of indirect WUI in Portugal, and identified substantial regional variations in the length and density of both kinds of WUI, reflecting differences in degree of urbanization and extent of wildlands, and indicating different levels of urban area exposure to wildfires. Addition of fire incidence data to the results of our analysis will permit the development of a WUI typology integrating urban area exposure to wildfires with wildfire threat magnitude, useful for fire management planning at the national level.
\end{abstract}

Keywords: Direct and indirect interface, Linear WUI, Portugal, Wildfires.

\section{Introduction}

Portugal has the highest wildfire incidence of all countries in southern Europe. During the last decade, there has been an increase in the number of incident reports in which buildings and homes were directly affected by wildfires. In 2017, Portugal recorded its worst fire season on record, both in terms of total area burned, loss of human lives, and property losses, with 470.000 ha burned, over 1000 homes destroyed or damaged, and 115 fatalities. Defining and identifying the wildland-urban interface (WUI) is relevant for risk assessment, land use planning, fire prevention and suppression, but it has not been done consistently for the whole country. The main goal of our study is to delineate and characterize the WUI in Portugal.

In fire-prone countries, the WUI has been a focus of research during the last two decades. WUIspecific maps are important both as pragmatic policy tools and as powerful images, with broad appeal (Stewart et al., 2009). There are several methodologies to map the WUI, and the main differences among them relate to data availability, study area size, and, most importantly, the objective of the map. Some WUI maps focus on assets (i.e., homes, infrastructure), while others focus on vegetation (Stewart et al., 2009). The common aspect of all maps is that they highlight wildfire as a social issue, because urban areas are exposed to wildfire risk due to their proximity to flammable fuels. Existing mapping methods vary not only in purpose, but also in scale. For example, in the United States the existing mapping methods reflect limited availability of housing data, as well as a broad-policy style, which 
does not encourage fine-scale mapping. Consequently, WUI maps use relatively large minimal mapping units, at the scale of housing clusters, neighborhoods, or settlements. Therefore, these maps rely on a threshold for housing density within a pre-defined area (census blocks or other data source), as well as on quantification of the vegetation density for each area (eg. Radeloff et al., 2005; Wilmer \& Aplet, 2005). This is an example of a zonal approach for WUI mapping.

Alternatives to zonal methods of WUI mapping use actual locations of homes or buildings. These point-based methods use the spatial coordinates for each individual building and have been developed in several European countries (Lampin-Maillet et al., 2009, 2010; Bar-Massada, Stewart, Hammer, Mockrin, \& Radeloff, 2013). A second approach combines elements of zonal and point-based methods. It relies on cadastral data and assumes that each parcel centroid represents the location of a building or building cluster (Platt, 2010). Other WUI mapping methods have used building location data, but none of them consistently addresses the three aspects of WUI definition, namely vegetation density, housing density and proximity of buildings to a large vegetated area.

We present a novel, semantically accurate approach to defining and mapping the WUI. Webster's Third New International Dictionary (Gove, 1961) defines "interface: a plane or other surface forming a common boundary of two bodies or spaces." Translating this concept to the two dimensions of a map, we define the WUI as the set of line segments where urban areas are in immediate physical contact with flammable vegetation (direct interface), or are less than a pre-specified distance away from flammable vegetation (indirect interface). The linear approach to the WUI definition and mapping provides great flexibility for information storage and utilization. Each WUI segment may be tagged with information about its adjoining urban area (area, population, number of buildings), and about its surroundings (types of adjacent fuels, flammable patch area, distance to the nearest flammable patch, topographic information, distance to roads, etc). Thus, the WUI concept we propose yields useful information for fire risk assessment, fuel management, and fire suppression planning. We mapped the WUI for the whole country and provided a summary at the county level.

\section{Methods}

\subsection{Study area}

Mainland Portugal extends over $89,015 \mathrm{~km}^{2}$, and is located between $37^{\circ} \mathrm{N}$ and $42^{\circ} \mathrm{N}$ latitude, and between $6^{\circ} \mathrm{W}$ and $10^{\circ} \mathrm{W}$ longitude. Portugal has a hot-summer Mediterranean climate (Köppen class Csa) in the southern half of the country, and a warm-summer mediterranean climate (Köppen class $\mathrm{Csb}$ ) in the northern half. The natural vegetation is typically evergreen, resistant to drought and pyrophytic, and regions with rugged terrain cover a substantial part of the country. These environmental conditions render the country quite susceptible to wildland fires and socio-economic and demographic trends reinforce this susceptibility. Many rural areas have experienced substantial population decreases since the mid-20th century, leading to the abandonment of agricultural lands, decrease in the sizes of herds, and a reduction in the consumption of forest fuels by animal grazing and fuelwood collection. Areas of marginally productive agriculture were converted to forest plantations or abandoned to the natural process of old-field succession, and reverted to shrublands and woodlands. These land use / land cover changes led to increases in the connectivity of high fuel loading vegetation patches, generating a landscape prone to the spread of large fires.

\subsection{Mapping the WUI}

Our analysis relied on the national land cover map COS 2015 (Carta de Ocupação do Solo para 2015 - COS2015) created by the Portuguese Land Planning and Mapping Agency (Direcção-Geral do Território - DGT). The map has a minimum mapping unit of 1 ha and a thematic legend with nine macroclasses (figure 1a) and 48 classes, which were reclassified to the four classes shown in figure $1 \mathrm{~b}$ 
to map the WUI. The degrees of urbanization map (figure 1c), from the DEGURBA classification (Dijkstra and Poelman, 2014) are defined as: densely populated areas, or cities, where at least $50 \%$ of the population lives in high-density clusters; intermediate density areas, or towns and suburbs, where less than $50 \%$ of the population lives in rural grid cells and less than $50 \%$ live in a high-density cluster; thinly populated areas, or rural areas, where more than $50 \%$ of the population lives in rural grid cells. The fire incidence map (figure 1d) data are from the Forest Research Centre (CEF) national fire perimeter atlas, complemented with data from the Institute for Nature Conservation and Forests (ICNF).
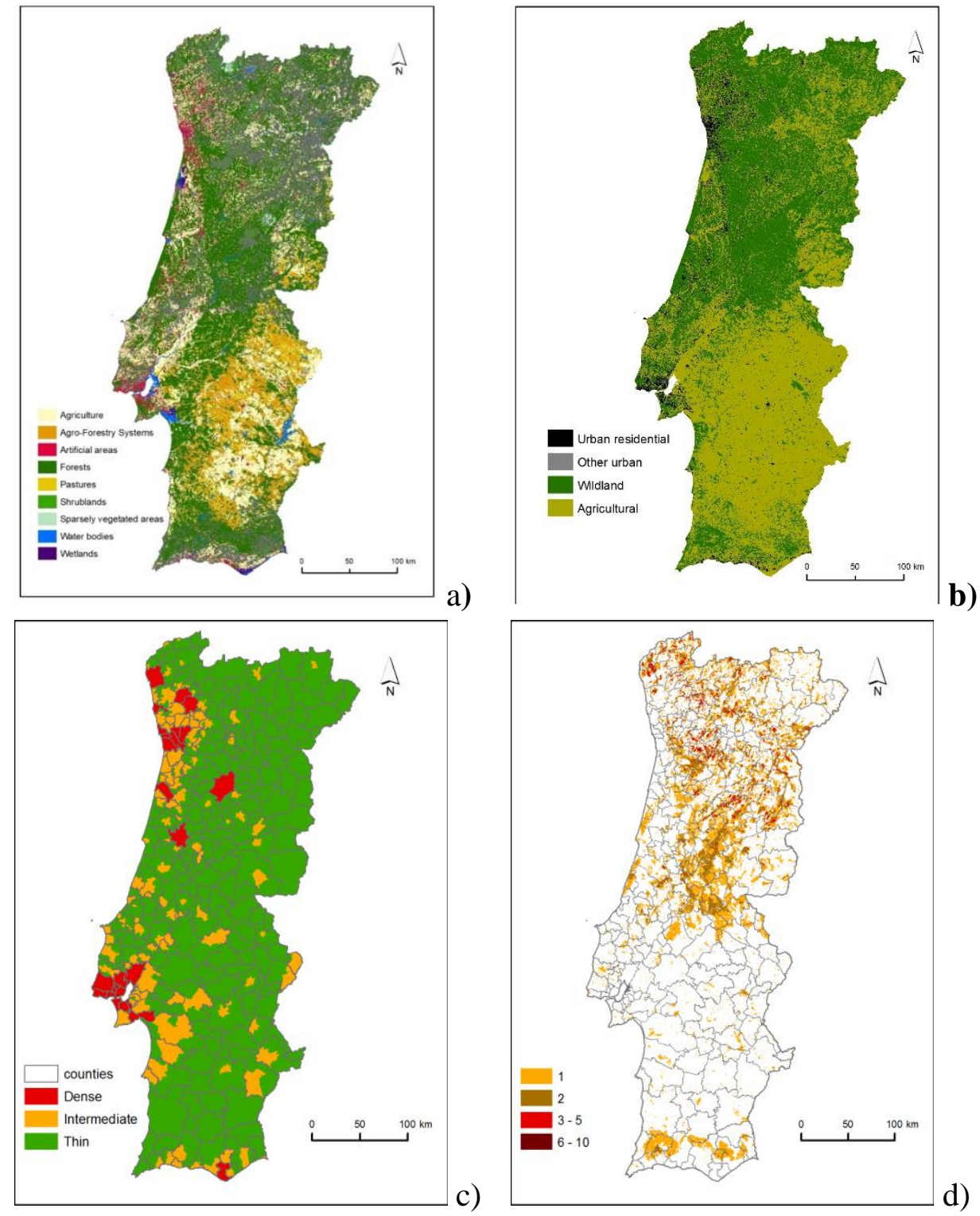

Figure 1 - a) Land cover megaclasses (COS2015); b) COS2015 simplified for WUI delineation; c) Degree of urbanization (DEGURBA) classification; d) number of times burned since 2000.

Delineation of the WUI depends primarily on the classes represented in Figure 1, "urban residential" and "Forests, shrublands, and pastures" (henceforth, wildland). We shall assume that urban area polygons and wildland area polygons share the same vertices whenever these vertices have the same location. Our definition of WUI relies on vertices rather than edges or polygons. This simplification was deemed necessary for computational efficiency reasons given the size of the data set to be analyzed. Following the legal definition of secondary fuelbreak network for the protection of settlements (Decree-Law n. ${ }^{\circ}$ 124/2006), only distances inferior to $100 \mathrm{~m}$ between urban and wildland 
patches have to be considered for the WUI delineation purpose. Therefore, we calculated, for every urban patch vertex its distance from all wildland patch vertices that lie inside a $100 \mathrm{~m}$ radius circle.

We say that an urban vertex $U$ is "protected" from its neighboring wildland vertices, if it is "protected" from all its wildland vertex neighbors within the $100 \mathrm{~m}$ range. This means that for each Wildland neighbor $\mathrm{W}$, there is an urban vertex $\mathrm{V}$ distinct from $\mathrm{U}$ that "protects" $\mathrm{U}$ from $\mathrm{W}$ in the following sense (see Figure 2):

- $\operatorname{dist}(\mathrm{U}, \mathrm{W})>0$, which guarantees that $\mathrm{U}$ cannot belong to the direct WUI (see below)

$-\operatorname{dist}(\mathrm{U}, \mathrm{V})<=\operatorname{dist}(\mathrm{U}, \mathrm{W})$ and $\operatorname{dist}(\mathrm{V}, \mathrm{W})<=\operatorname{dist}(\mathrm{U}, \mathrm{W})$, which guarantees that $\mathrm{U}$ lies "between" $\mathrm{V}$ and $\mathrm{W}$;

$-\operatorname{dist}(\mathrm{U}, \mathrm{V})+\operatorname{dist}(\mathrm{V}, \mathrm{W})<\operatorname{dist}(\mathrm{U}, \mathrm{W}) * \mathrm{~T}$, where $\mathrm{T}>1$ is an user-defined threshold $(\mathrm{T}=1.05$ provided good results).

The key condition is the last one, which states that the three vertices $\mathrm{U}, \mathrm{V}$ and $\mathrm{W}$ are nearly aligned to $5 \%$ tolerance $(\mathrm{T}=1.05)$, with $\mathrm{V}$ lying between $\mathrm{U}$ and $\mathrm{W}$. This condition is an alternative implementation, using vertices, of the intuitive idea that a vertex of a urban polygon is exposed to (i.e., not protected from) the wildland, if it can be connected by a straight line to some neighboring wildland vertex without intersecting other urban edges. In order to make this approach more effective, a previous densification of the number of vertices in each edge of the urban polygons was performed, such that no two consecutive vertices are more than $40 \mathrm{~m}$ apart. This is a good compromise between spatial accuracy and computational effort.

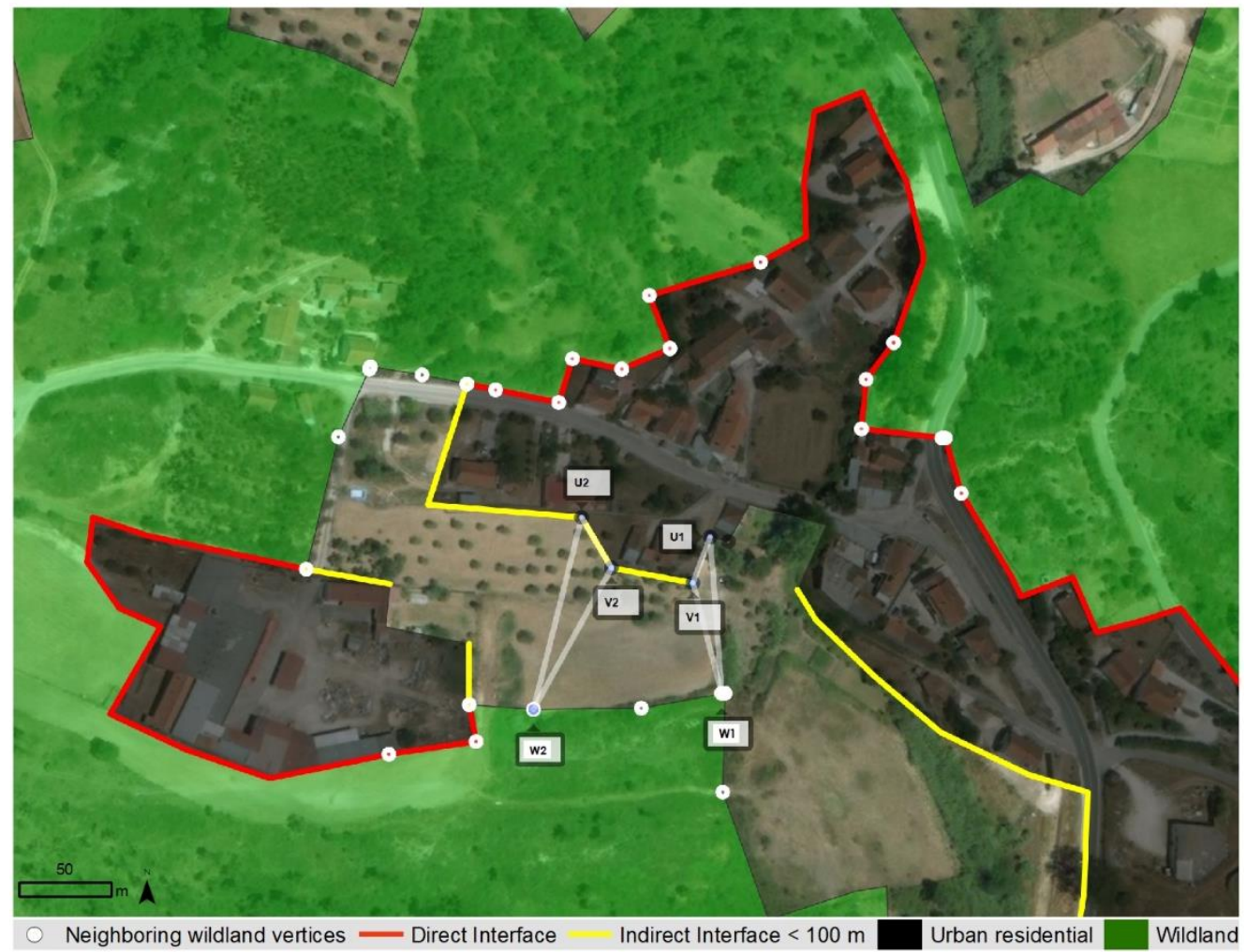

Figure 2 - WUI delineation method: the red [yellow] edges of the two urban polygons delineate the direct [indirect] WUI. Vertices U1, V1 and W1 are nearly aligned within the 5\% tolerance

$(\operatorname{dist}(U 1, V 1)+\operatorname{dist}(V 1, W 1)<1.05 * \operatorname{dist}(U 1, W 1))$, and therefore urban vertex $U 1$ is protected from Wildand vertex W1 by urban vertex $V 1$. On the contrary, urban vertex $U 2$ is exposed to the Wildand vertex $W 2$, since it is not protected by urban vertex V2 (dist $(U 2, V 2)+\operatorname{dist}(V 2, W 2)>=1.05 * \operatorname{dist}(U 2, W 2))$.

Using the concept described above, we define the linear WUI, as the set of edges belonging to urban polygons that have both of its vertices exposed to neighboring wildland vertices (within the $100 \mathrm{~m}$ range). In particular, two kinds of WUI can be immediately distinguished: the direct WUI (red lines in 
figure 2), where wildland and urban areas are adjacent to each other, and the indirect WUI (yellow lines in figure 2), where agroforestry, cropland, or other non-flammable land cover types, lie inbetween. Evidently, the former case implies a greater exposure of the urban area to a potential wildfire, while in the latter case agricultural areas, bare ground, or water bodies, may provide some protection to the urban area.

\section{Results}

The COS2015 land cover map contains 46480 residential urban polygons, of which 40319 correspond to some kind of WUI. Our algorithm identified $29977 \mathrm{~km}$ of direct WUI and $11192 \mathrm{~km}$ of indirect WUI. Figure 3 shows the WUI at Fafe (a), in NW Portugal, and at Vila de Rei, in the center of the country (b).
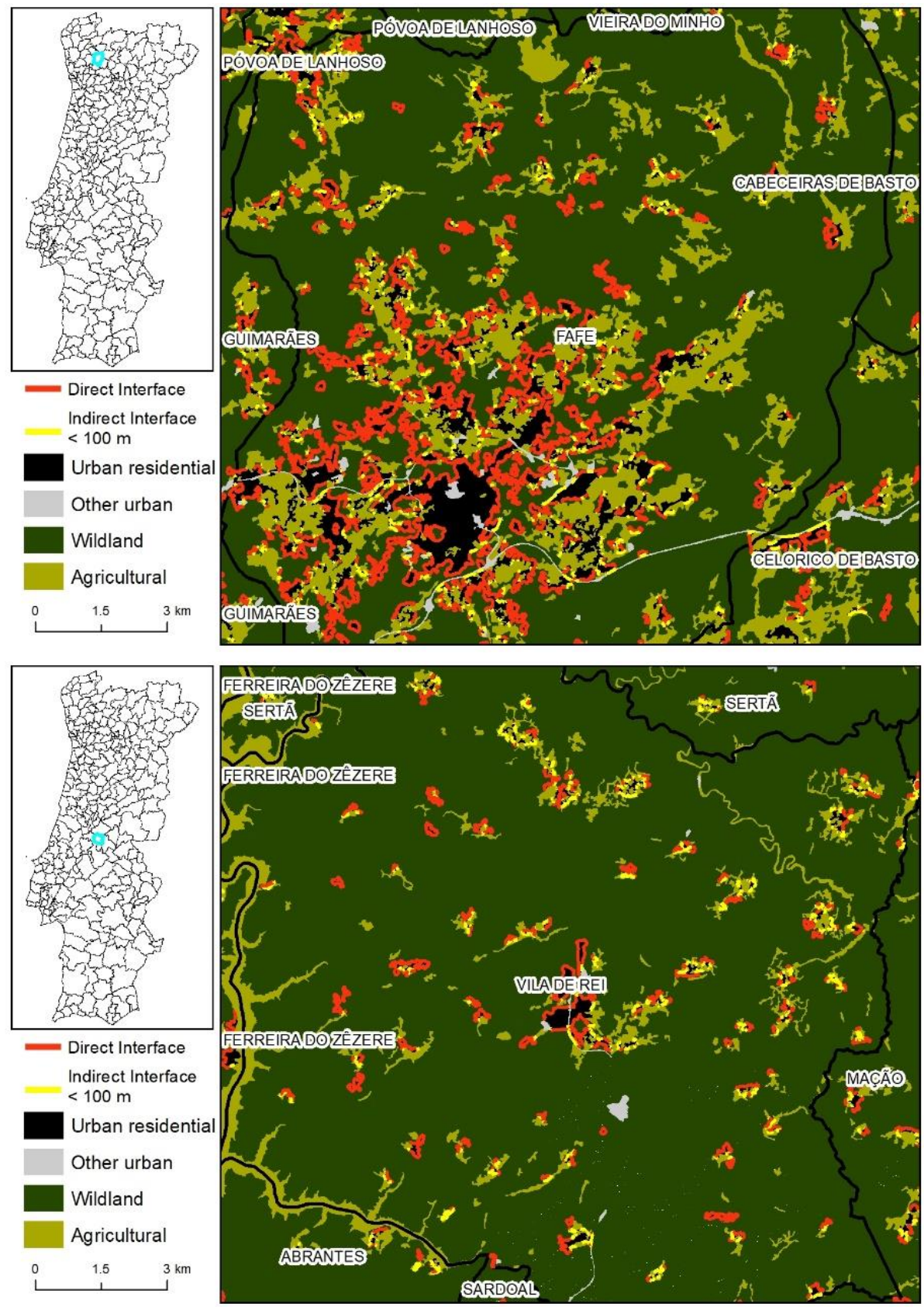

Figure 3 - Direct and indirect WUI at Fafe (a) and Vila de Rei (b), sites with contrasting land use and settlement patterns. 
The WUI length and type at the two sites is very distinct, reflecting differences in land use / land cover patterns. Fafe has a long, mostly direct WUI, while Vila de Rei has a shorter WUI, but with a higher proportion of indirect WUI than at Fafe. This landscape-level overview reveals the detailed information provided on the location, extent, and shape of the linear WUI.

Figures 4 and 5 display results of a country-wide WUI analysis of the COS2015 land cover map, aggregated at the municipal level. Figure 4 shows that the geographical patterns of direct WUI (a) and indirect WUI (b) are similar, despite quantitative differences, since the length of direct WUI are about three times higher than those of the indirect WUI.

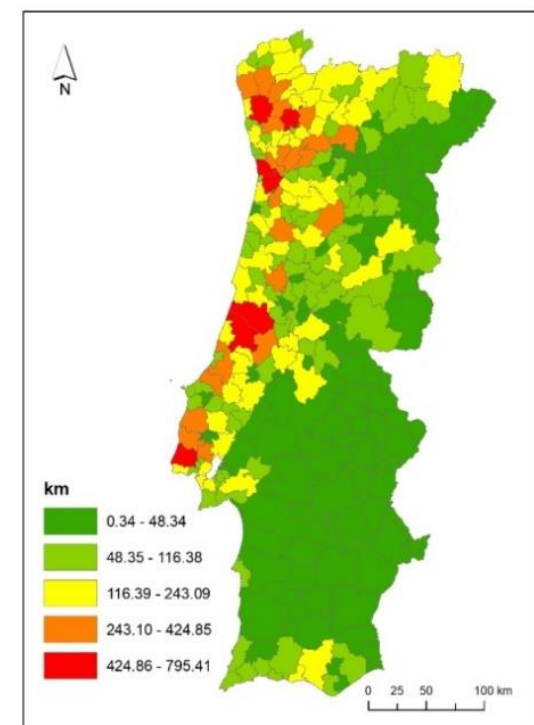

a)

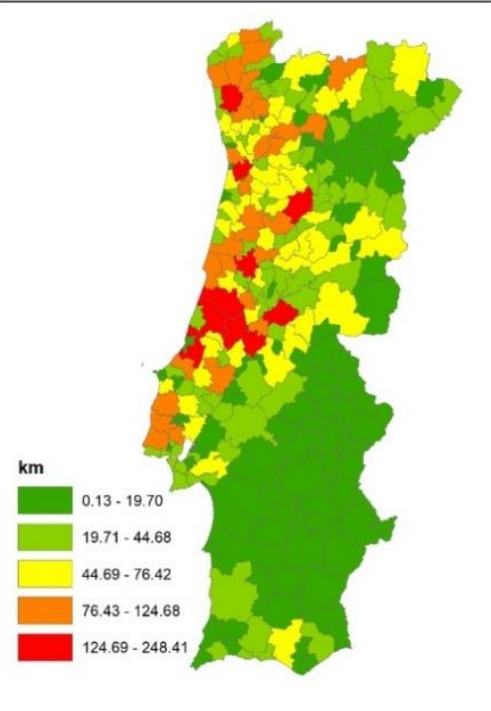

b)

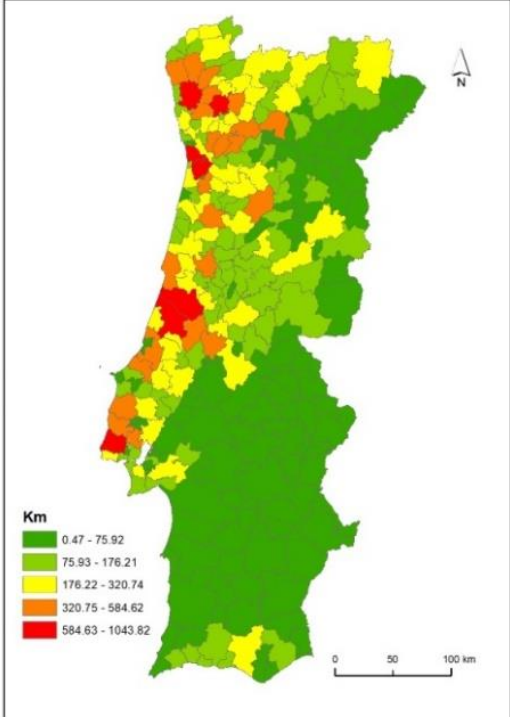

c)

Figure 4 - Length of direct (a), indirect (b) and total (direct + indirect) WUI.

Figure $4 \mathrm{c}$ shows that the largest extent of total WUI occur in regions with dense and intermediate degrees of urbanization (figure 1c), but also in a thinly urbanized coastal area in the center of the country. Rural regions in northeastern and southern Portugal display low WUI values.

WUI density (figure 5) is the ratio of WUI length to urban area. It displays substantially different geographical patterns from those shown in Figure 4, and clear distinctions between direct (a) and indirect (b) WUI.

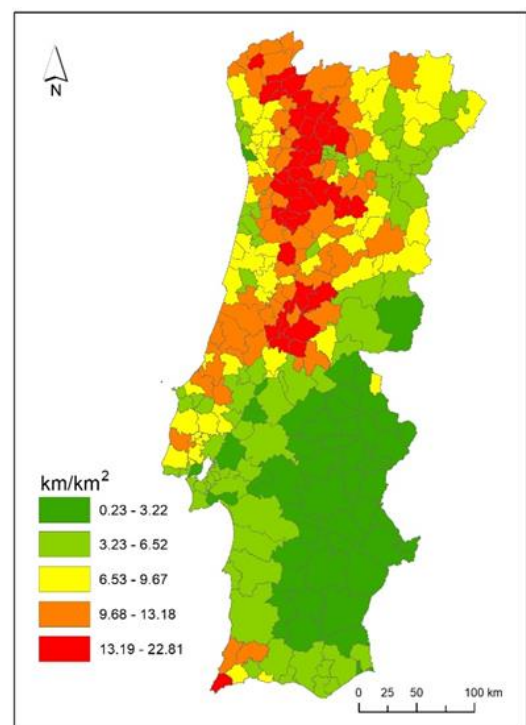

a)

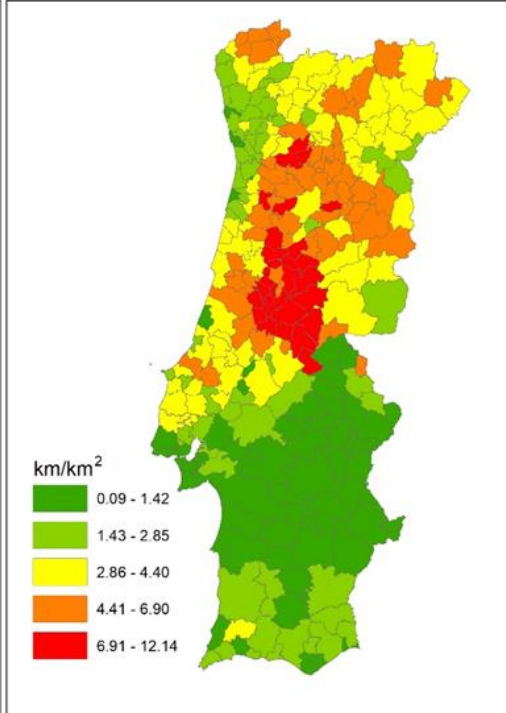

b)

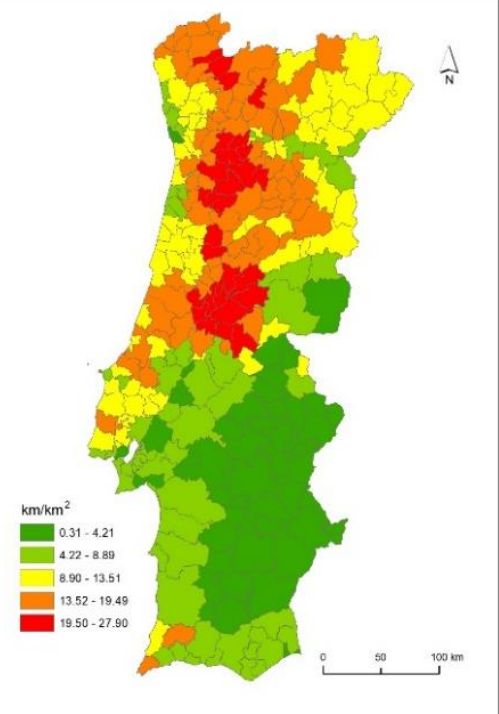

c)

Figure 5 - Direct (a), indirect (b) and total (direct + indirect) WUI density. 
Unlike WUI length, WUI density peaks in areas classified as thinly urbanized, or rural, in figure 3c. Direct WUI density (5a) is highest in NW Portugal, inland from the areas with the longest absolute WUI shown in figure $4 \mathrm{a}$, and in thinly urbanized, densely forested central region of the country. This area also has the highest values of indirect WUI density. The lowest values of direct WUI density occur in agricultural areas of rural southern Portugal. The areas with the highest total WUI density are some of the most fire-prone regions in the country (figure 1d).

\section{Discussion and Conclusions}

The linear WUI mapping algorithm we propose can be implemented over large areas, provides very detailed information on the location, extent and shape of the interface, and proved to be sensitive to variations in population density and land use. Referring back to the two test sites presented in figure 3, Fafe has 2094 inhabitants. $\mathrm{km}^{-2}$ and a landscape with relatively large areas of urban and agricultural land uses, while Vila de Rei has 18 inhabitants. $\mathrm{km}^{-2}$ and small patches of urban and agricultural areas in a forest-dominated landscape. Despite the large proportion of agricultural land in Fafe, there is extensive adjacency between urban areas and wildlands and, therefore, most of its WUI is direct interface. On the contrary, at Vila de Rei, the small patches of agricultural land surround most of the settlements, and thus a large proportion of the WUI is indirect. WUI delineation methodologies based on a coarser analysis of the relative abundance and spatial structure of the land cover might have missed this counter-intuitive result. The detailed and precise delineation of WUI segments along the perimeter of urban areas may be useful to monitor and manage the impact on WUI extent and density of processes like urban growth, cropland abandonment, and forest encroachment on rural villages.

In the densely urbanized areas of Portugal, the relative proportions and spatial distribution patterns of urban areas and wildlands produce the largest extents of linear WUI, both direct and indirect. However, city size implies that most of the built-up land is interior to the urban area, i.e. located at a relatively safe distance from the WUI. Since fire incidence typically is low in these regions, the combination of limited urban area exposure and low magnitude wildfire threat is conducive to a moderate fire risk situation. As expected, the shortest WUI values are found in predominantly agricultural rural regions, where both urban areas and wildlands are scarce. WUI density is a good metric of exposure, because landscape patches with high perimeter-to-area ratio (interface length per unit area of urban land patch) are permeable to flows from their environment, such as the energy released by a wildfire. This explains the predominant location of the highest WUI densities in thinly urbanized areas, with small rural settlements and extensive forests and shrublands. Exposed settlements in areas of high fire incidence are under severe fire risk, as tragically demonstrated in June and October, 2017. Our approach characterizes the WUI at a very detailed level as segments of the perimeter of individual settlements, with associated attributes of length, area of the adjacent urban and wildland polygons and, in the case of the indirect WUI, distance between urban area and wildland. This information concerning each WUI segment can be aggregated at the settlement level and employed to develop a WUI typology useful for setting fire prevention and suppression priorities and strategies, namely an improved delineation of the mandatory secondary fuelbreak network for the protection of rural villages and towns in fire-prone landscapes.

\section{Acknowledgments}

The research reported herein was performed under research project PTDC/AGR-FOR/2586/2014 Fire in the Rural-Urban Interface: characterisation, risk mapping, and fuel break design (RurIntFire), funded by the Foundation for Science and Technology (FCT). The Centro de Estudos Florestais (CEF) is a research unit funded by Fundação para a Ciência e a Tecnologia I.P. (FCT), Portugal (UID/AGR/00239/2013). 


\section{References}

Bar-Massada, A., Stewart, S. I., Hammer, R. B., Mockrin, M. H., \& Radeloff, V. C. (2013). Using structure locations as a basis for mapping the wildland urban interface. Journal of Environmental Management, 128, 540-547.

Dijkstra, L., \& Poelman, H. (2014). A harmonised definition of cities and rural areas: the new degree of urbanisation. Regional Working Paper 2014. DG Regional and Urban Policy, European Commission, Brussels, Belgium.

Gove, P. B. (1961). Webster's Third New International Dictionary of the English Language, unabridged. (P. B. Gove, Ed.). Springfield, Mass.: G\&C Merriam Company.

Lampin-Maillet, C., Jappiot, M., Long, M., Morge, D., Ferrier, J.P., 2009. Characterization and mapping of dwelling types for forest fire prevention. Computers, Environment and Urban Systems 33, 224-232.

Lampin-Maillet, C., Jappiot, M., Long, M., Bouillon, C., Morge, D., Ferrier, J.P., 2010. Mapping wildland-urban interfaces at large scales integrating housing density and vegetation aggregation for fire prevention in the south of France. Journal of Environmental Management 91, 732-741.

Lampin-Maillet, C., Long-Fournel, M., Ganteaume, A., Jappiot, M., \& Ferrier, J. P. (2011). Land cover analysis in wildland-urban interfaces according to wildfire risk: A case study in the South of France. Forest Ecology and Management, 261, 2200-2213.

Platt, R. (2010). The Wildland Urban Interface: Evaluating the Definition Effect. Journal of Forestry, 108, 9-15.

Radeloff, V. C., Hammer, R. B., Stewart, S. I., Fried, J. S., Holcomb, S. S., \& McKeefry, J. F. (2005). The wildland-urban interface in the United States. Ecological Applications, 15(3), 799-805.

Stewart, S. I., Wilmer, B., Hammer, R. B., Aplet, G. H., Hawbaker, T. J., Miller, C., \& Radeloff, V. C. (2009). Wildland-urban interface maps vary with purpose and context. Journal of Forestry, 107(2), 78-83.

Wilmer, B., \& Aplet, G. (2005). Targeting the community fire planning zone: Mapping matters. Washington, DC: the Wilderness Society. 